\title{
高齢者胸腰椎圧迫骨折に対する Jewett型軟性コルセットの治療成績
}

\author{
土田 敏典 ${ }^{1)} \quad$ 赤崎外志也 ${ }^{1)}$ 青木 $\quad$ 優 ${ }^{1)}$ \\ 内藤 充啓 ${ }^{11}$ 釜下 厚則 ${ }^{2}$
}

Key words $\square$ 装具 (Corset), 胸腰椎 (Thoracic-lumbar vertebra), 圧迫骨折 (Compression fracture)

\begin{abstract}
要旨 :【目的】高齢者の胸腰椎移行部圧迫骨折に対し，今回作製したJewett型軟性コ ルセットを用い治療した．【対象および方法】対象は胸腰椎移行部圧迫骨折の7例で， 平均 79.7 歳であった。治療方法は, 1 例には体幹ギプス固定後, 他の 6 例は $1 \sim 2$ 週間 の安静臥床後, Jewett型コルセットを装着し起立歩行訓練を開始した . 治療成績を腰 痛疾患のJOA-score，X線学的に損傷椎体の楔状率を評価した。【結果】全例腰痛は軽 減し，元の歩行状態に復帰した. JOA-scoreは受傷直後平均 10.1 点から調査時 20.3 点 となった，椎体楔状率は $78.5 \%$ から $62.0 \%$ となった .【考察および結論】Jewett型硬性 腰椎装具では腰背部と胸骨と骨盤部での 3 点固定理論により脊椎支持安定効果がある が，重く装着に困難であった .今回，新たに作製したJewett型軟性コルセットは，軽 く装着が容易で腹部を圧迫しないため肥満患者にも有用であった .
\end{abstract}

\begin{abstract}
Summary
Seven patients diagnosed with thoracic-lumbar compression fracture were treated using the Jewett type elasticity corset. In clinical evaluation, JOA-scores for low back pain were measured. In roentgenographical evaluation, the wedge condition ratio of the damaged vertebral body was measured. All patients' lumbagos were decreased, and all returned to original walking state. JOA-score returned to an average of 20.3 points from an average of 10.1 points. The wedge condition ratio of vertebral body returned to an average of $62.0 \%$ from an average of $78.5 \%$. The Jewett type hard vertebral equipment supports the body in the waist back section and the sternum and the pelvis based upon a three point fixed theory. The hard vertebral corset was heavy and was difficult for patients to wear. The newly produced Jewett type elasticity corset was easy to fit, wear and remove, and because it did not press an abdomen, it was appropriate for overweight patients.
\end{abstract}

Toshinori TSUCHIDA et al : Clinical result of Jewett type elasticity corset for thoracic-lumbar vertebral compression fracture

1) 恵寿総合病院整形外科〔干 926-8605 七尾市富岡町 94〕

2) 同 義肢装具室 


\section{緒 言}

高齢者では軽微な外傷で胸腰椎移行部圧迫 骨折が起こりやすい．多くの症例に保存的治 療法が行われ，硬性コルセットや胸腰椎ダー メン軟性コルセットが装着されるが，高齢者 や肥満者では装着がしにくいことが多い，光 こで今回，われわれが考案作製した Jewett 型軟性コルセットを用い治療したので報告す る。

\section{I. 対象および方法}

対象は胸腰椎移行部圧迫骨折の 7 例 (男性 1 例，女性 6例) で, 年齡は $70 \sim 87$ 歳 (平均 79.7 歳), 肥満度 (BMI) は $17.5 \sim 30.6$ (平均 22.0 )であった . 骨密度 (DEXA) は平均 0.398 $\mathrm{g} / \mathrm{cm}^{2}$ (YAM比 58 \%) であった . 今回使用し た Jewett型軟性コルセットは従来のダーメ ン型軟性コルセットと比し，後方の金属板を 増やし，前方には上下体幹を人工皮革製ベル 卜で固定し，弚の間を空けた軟性あるいは半 硬性の装具である(図1).

治療方法は，1例には体幹ギプス固定後に， 他の 6 例は $1 \sim 2$ 週間の安静臥床の後，
Jewett型軟性コルセットを装着し起立歩行訓 練を開始した，治療成績を日整会腰痛疾患成 績判定基準 (以下, JOA-score と略す) を用い て，またX線学的に損傷椎体の楔状率を評価 した. 経過観察期間は 1 年 4 力月〜 4 年, 平 均 2 年 4 力月であった .

\section{II. 結 果}

全例腰痛は軽減し, 受傷前の歩行状態に復 帰することができた . JOA-scoreは受傷直後 平均 10.1 点 (自覚症状 3.7 点, 他覚所見 5.6 点, 日常生活動作 0.9 点) から調査時平均 20.3 点 (自覚症状 7.0 点, 他覚所見 5.4 点, 日常生活 動作 7.9点) となった (図 2). 椎体楔状率は受 傷直後平均 $78.5 \%(50 \sim 100 \%)$ から調査時 平均 $62.0 \%$ (36.7〜 100\%) となった (図3).

\section{III. 症例提示}

症例：70歳, 女性. 第 12 胸椎圧迫骨折. 自宅で転倒し受傷した。体幹ギプス固定 2 週 間後から Jewett型軟性コルセットを装着し た.JOA-scoreは受傷直後 7 点から調査時 20 点となった．X線学的に椎体楔状率は受傷直 後 $95.7 \%$ から 1 カ月後 $60.1 \%$ と椎体圧潰が進

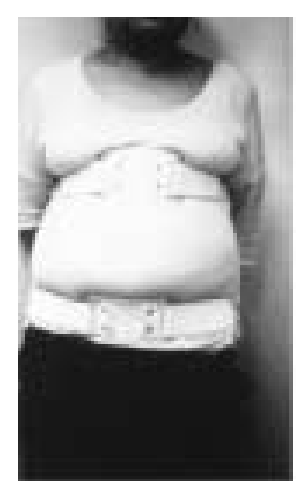

a) 正面像

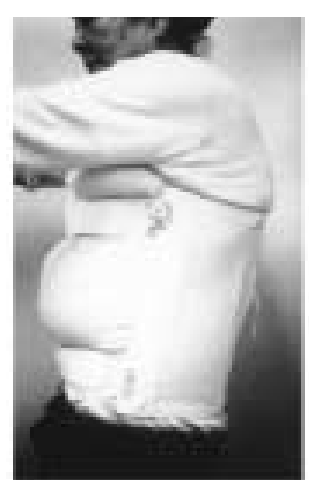

b) 側面像

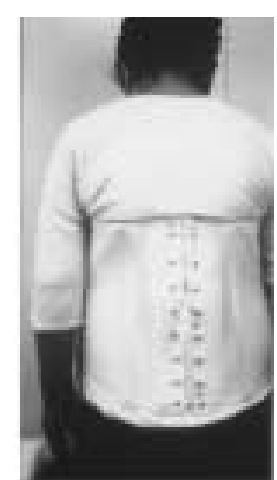

c) 後面像

図1 Jewett型軟性装具

ダーメン型軟性コルセットと比し，前面の腹帯をできる限り削除している． 


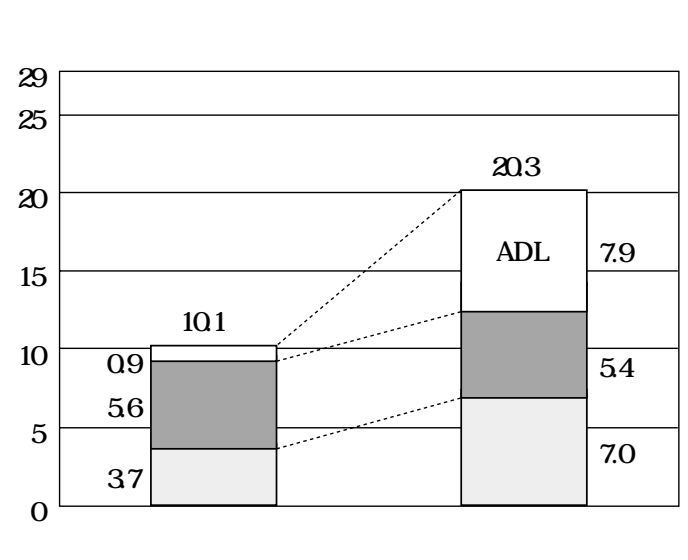

図2 日整会腰痛疾患成績判定基準 (JOA-score) の 変化

JOA-score は受傷直後平均 10.1 点から調査時平均 20.3 点に改善した .

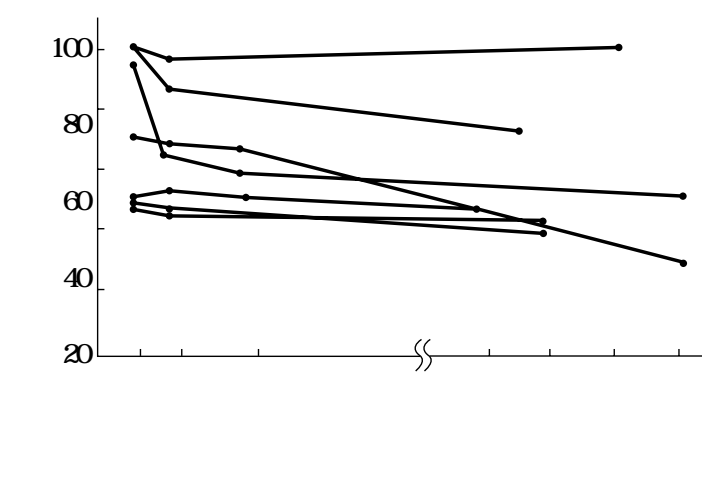

図3X線学的評価 (椎体楔状率)

椎体楔状率は受傷直後平均 $78.5 \%$ から調査時平均 $62.0 \%$ に低下した 。

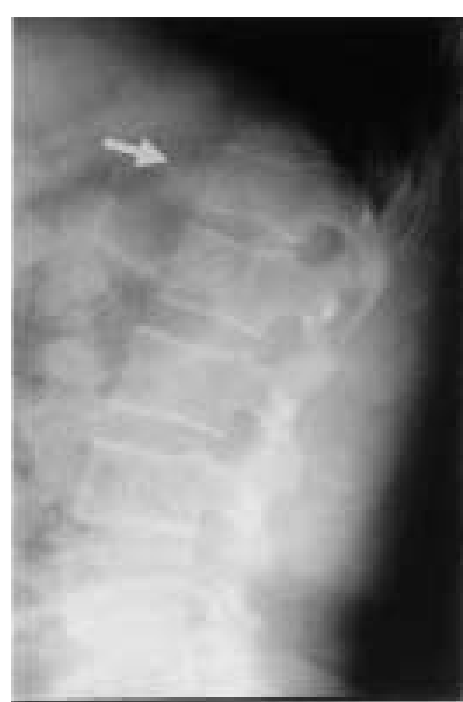

a) 受傷直後

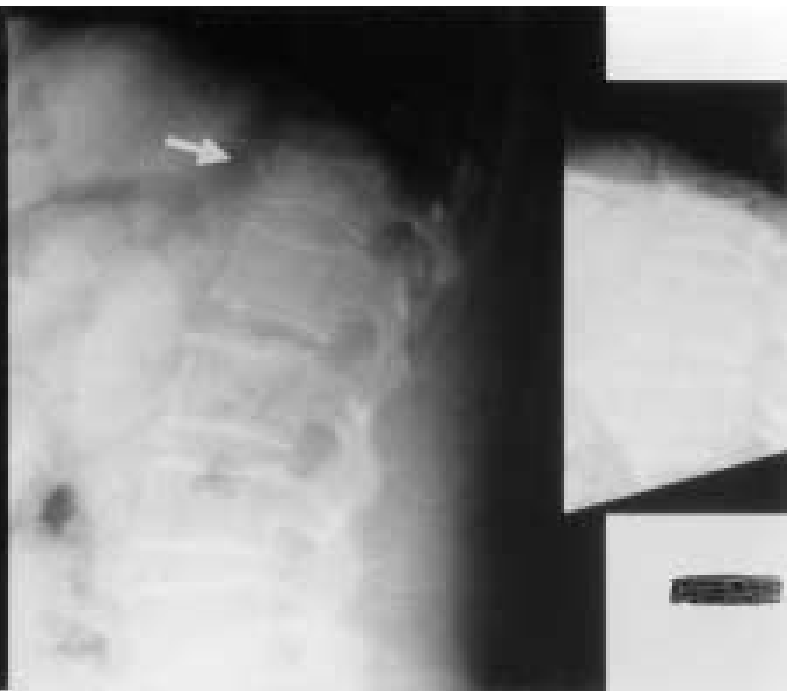

b) 1 力月後 c) 4 年後

図4 症例：70歳, 女性, 第 12 胸椎圧迫骨折

第 12 胸椎 (矢印) の椎体楔状率は受傷直後 $95.7 \%$ から 1 力月後に $60.1 \%, 4$ 年後に $53.6 \%$ となった .

行したが, 弚の後は軽度の進行に留まり, 4 年後の現在は $53.6 \%$ である (図 4) .

$$
\text { IV. 考 察 }
$$

胸腰椎装具の目的は胸腰椎の安定性の維持 や負荷を減少することである . 軟性装具は腰 腹部を全周性に支持することで腹腔内圧を上
昇させ , 腰背筋にかかる負荷を減少させる効 果があるとされる ${ }^{1)}$. しかし, 体幹装具の腹 腔内圧上昇効果の懷疑的な報告もある ${ }^{2)}$.ま た, 肥満患者では従来のコルセットでは固定 性が不良であり，肥満度に応じて固定方法を 変更すべきとの報告もある ${ }^{5)}$. 乥れに対し， Jewett型硬性装具では腰背部と胸骨胁骨部と 
骨盤部での支持による 3 点固定理論により脊 椎支持安定効果がある ${ }^{4)}$. Jewett型硬性脊椎 装具では前屈が制限されるが後屈は制限せ ず，腹部を圧迫しないため肥満患者にも有用 である3).ただし，硬性であるため，重く装 着に困難であった .今回，新たに作製した Jewett型軟性コルセットは, 軽く装着が容易 であり，ダーメン型軟性コルセットに比し腹 圧上昇効果は少ないものの, 腹部圧迫感がな いため肥満者には有効であった .

$$
\text { まとめ }
$$

高齢者の胸腰椎移行部圧迫骨折 7 例に対 し Jewett型軟性コルセットを用い治療した . 全例腰痛は軽減し, 受傷前の歩行状態に復帰 した。

JOA-score は受傷直後平均 10.1 点から調査 時平均 20.3 点となった . 椎体楔状率は受傷直 後平均 $78.5 \%$ から調査時平均 $62.0 \%$ となった .
本研究を遂行するにあたり，こ協力いただいた金 沢義肢製作所の山岸久人樣, 吉田惠一樣に深謝しま す.

\section{文献}

1) Harman EA, Rosenstein RM, Frykman PN et al. Effect of a belt on intra-abdominal pressure during weight lifting. Med Sci Sports Exerc. 1989 ; $21: 186-190$.

2) Majkowski GR, Jovag BW, Taylor BT et al. The effect of back belt use on isometric lifting force and fatigue of the lumbar paraspinal muscles. Spine. $1998 ; 23: 2104-2109$.

3) 丸山 徹. 胸腰仙椎装具 - 頚椎装具 - 頚胸椎装 具. 整形外科看護 . $2000 ; 5: 1213-1219$.

4) 宮本雅史 .急性腰痛症に対する装具療法. MB Orthop. 2000; 13:33-36.

5) 戶田佳孝, 加藤章子, 山本節子ほか. 腰痛患者 に対するコルセットの効果と満との関連性なら びに後方言引バンド付きコルセットの考案 . 整 形外科 . $2002 ; 53: 235-239$. 